\title{
Concentrations and Sources of Organic Carbon Aerosol in the Free Troposphere over North America
}

\section{Citation}

Heald, Colette L., Daniel J. Jacob, Solene Turquety, Rynda C. Hudman, Rodney J. Weber, Amy P. Sullivan, Richard E. Peltier, et al. 2006. Concentrations and sources of organic carbon aerosol in the free troposphere over North America. Journal of Geophysical Research 111: D23S47.

\section{Published Version}

doi:10.1029/2006JD007705

\section{Permanent link}

http://nrs.harvard.edu/urn-3:HUL.InstRepos:3743670

\section{Terms of Use}

This article was downloaded from Harvard University's DASH repository, and is made available under the terms and conditions applicable to Other Posted Material, as set forth at http:// nrs.harvard.edu/urn-3:HUL.InstRepos:dash.current.terms-of-use\#LAA

\section{Share Your Story}

The Harvard community has made this article openly available.

Please share how this access benefits you. Submit a story.

\section{Accessibility}




\title{
Concentrations and sources of organic carbon aerosols in the free troposphere over North America
}

\author{
Colette L. Heald, ${ }^{1,2}$ Daniel J. Jacob, ${ }^{3}$ Solène Turquety, ${ }^{3,4}$ Rynda C. Hudman, ${ }^{3}$
}

Rodney J. Weber, ${ }^{5}$ Amy P. Sullivan, ${ }^{5}$ Richard E. Peltier, ${ }^{5}$ Eliot L. Atlas, ${ }^{6}$

Joost A. de Gouw, ${ }^{7,8}$ Carsten Warneke, ${ }^{7,8}$ John S. Holloway, ${ }^{7,8}$ J. Andrew Neuman, ${ }^{7,8}$

Frank M. Flocke, ${ }^{9}$ and John H. Seinfeld ${ }^{10}$

Received 27 June 2006; revised 22 August 2006; accepted 9 October 2006; published 12 December 2006.

[1] Aircraft measurements of water-soluble organic carbon (WSOC) aerosol over NE

North America during summer 2004 (ITCT-2K4) are simulated with a global chemical transport model (GEOS-Chem) to test our understanding of the sources of organic carbon (OC) aerosol in the free troposphere (FT). Elevated concentrations were observed in plumes from boreal fires in Alaska and Canada. WSOC aerosol concentrations outside of these plumes average $0.9 \pm 0.9 \mu \mathrm{g} \mathrm{C} \mathrm{m}^{-3}$ in the FT $(2-6 \mathrm{~km})$. The corresponding model value is $0.7 \pm 0.6 \mu \mathrm{g} \mathrm{C} \mathrm{m}^{-3}$, including $42 \%$ from biomass burning, $36 \%$ from biogenic secondary organic aerosol (SOA), and 22\% from anthropogenic emissions. Previous OC aerosol observations over the NW Pacific in spring 2001 (ACE-Asia) averaged $3.3 \pm 2.8 \mu \mathrm{g} \mathrm{C} \mathrm{m}^{-3}$ in the FT, compared to a model value of $0.3 \pm 0.3 \mu \mathrm{g} \mathrm{C} \mathrm{m}^{-3}$. WSOC aerosol concentrations in the boundary layer (BL) during ITCT-2K4 are consistent with OC aerosol observed at the IMPROVE surface network. The model is low in the boundary layer by $30 \%$, which we attribute to secondary formation at a rate comparable to primary anthropogenic emission. Observed WSOC aerosol concentrations decrease by a factor of 2 from the BL to the FT, as compared to a factor of 10 decrease for sulfate, indicating that most of the WSOC aerosol in the FT originates in situ. Despite reproducing mean observed WSOC concentrations in the FT to within $25 \%$, the model cannot account for the variance in the observations $(R=0.21)$. Covariance analysis of FT WSOC aerosol with other measured chemical variables suggests an aqueous-phase mechanism for SOA generation involving biogenic precursors.

Citation: Heald, C. L., et al. (2006), Concentrations and sources of organic carbon aerosols in the free troposphere over North America, J. Geophys. Res., 111, D23S47, doi:10.1029/2006JD007705.

\section{Introduction}

[2] Organic carbon (OC) aerosols constitute a large fraction of the total aerosol mass in the troposphere, yet the processes which dictate their formation remain highly uncertain. Sources include primary emission from biomass burning and fuel use, as well as secondary production from the oxidation of volatile organic compounds (VOCs) [IPCC, 2001]. Recent field observations indicate that the secondary production of $\mathrm{OC}$ aerosols is considerably underestimated in current models, both in surface air [de Gouw et al., 2005; Johnson et al., 2006; Volkamer et al., 2006] and

\footnotetext{
${ }^{1}$ Center for Atmospheric Sciences, University of California, Berkeley, California, USA.

${ }^{2}$ Formerly at Division of Engineering and Applied Science, Harvard University, Cambridge, Massachusetts, USA.

${ }^{3}$ Division of Engineering and Applied Science, Harvard University, Cambridge, Massachusetts, USA.

${ }^{4}$ Now at Service d'Aeronomie, Institut Pierre-Simon Laplace, Paris, France.

Copyright 2006 by the American Geophysical Union. 0148-0227/06/2006JD007705\$09.00
}

in the free troposphere [Heald et al., 2005]. We use here observations of OC aerosol from the NOAA Intercontinental Transport and Chemical Transformation 2004 (ITCT-2K4) aircraft campaign over eastern North America, together with surface observations and simulations with a global chemical transport model (GEOS-Chem), to gain further insight into the processes controlling $\mathrm{OC}$ aerosol abundances with a focus on the free troposphere.

[3] The ITCT-2K4 aircraft campaign was conducted from 9 July to 15 August 2004 out of Portsmouth, New Hampshire, as part of a broader International Consortium for Atmospheric Research on Transport and Transformation

\footnotetext{
${ }^{5}$ School of Earth and Atmospheric Sciences, Georgia Institute of Technology, Atlanta, Georgia, USA.

${ }^{6}$ Rosentiel School of Marine and Atmospheric Science, University of Miami, Miami, Florida, USA.

${ }^{7}$ Chemical Sciences Division, NOAA Earth System Research Laboratory, Boulder, Colorado, USA.

${ }^{8}$ Also at Cooperative Institute for Research in Environmental Sciences, University of Colorado, Boulder, Colorado, USA.

${ }^{9}$ National Center for Atmospheric Research, Boulder, Colorado, USA.

${ }^{10}$ Department of Chemical Engineering, California Institute of Technology, Pasadena, California, USA.
} 
(ICARTT) involving several aircraft operating in eastern North America and addressing regional pollution and continental export issues. The focus of ITCT-2K4 was to observe the aging of urban and power plant pollution plumes, the regional transport of pollution from the Midwest to the northeastern United States, and the continental outflow from eastern North America to the global atmosphere. Extensive gas phase and aerosol chemical measurements were made aboard the NOAA WP3 aircraft up to $6 \mathrm{~km}$ (flight tracks shown in Figure 1). Included in this suite of instrumentation was the first aircraft deployment of a Particle-Into-Liquid Sampler (PILS) instrument for measuring water-soluble organic carbon (WSOC) aerosol [Sullivan et al., 2006]. This represents the most extensive data set so far of $\mathrm{OC}$ aerosol concentrations in the free troposphere, and enables correlative analyses with other species measured aboard the aircraft. WSOC aerosol is thought to include secondary organic aerosol (SOA) as well as aged primary components of OC aerosol [Saxena and Hildemann, 1996; Decesari et al., 2001], and thus to account for most of OC aerosol mass in air remote from primary sources [Jaffrezo et al., 2005, and references therein].

[4] The summer of 2004 was a particularly strong fire year in the boreal regions of Alaska and NW Canada. The National Interagency Coordination Center (NICC) estimates that 2.6 million ha burned in Alaska in 2004, 8 times the 10 -year average for the region. Biomass-burning emissions were a substantial perturbation to the atmosphere during ITCT-2K4, with plumes transported across North America and the Atlantic Ocean [Lewis et al., 2006; Morris et al., 2006] (S. Turquety et al., Inventory of boreal fire emissions for North America: Importance of peat burning and pyroconvective injection, submitted to Journal of Geophysical Research, 2006; hereinafter referred to as Turquety et al., submitted manuscript, 2006). De Gouw et al. [2006] identified fire plumes with elevated acetonitrile, $\mathrm{CO}$ and particle volume in 8 of the 18 ITCT-2K4 flights over eastern North America. Sullivan et al. [2006] show that these plumes contained elevated WSOC aerosol.

[5] The GEOS-Chem global chemical transport model (CTM) used here to interpret the ITCT-2K4 WSOC aerosol data has been applied previously to a number of aerosol studies over North America and Asia [Park et al., 2003, 2004, 2005, 2006; Heald et al., 2005, 2006; van Donkelaar et al., 2006a, 2006b; T. D. Fairlie et al., The impact of transpacific transport of mineral dust in the United States, submitted to Atmospheric Environment, 2006]. Park et al. [2003, 2006] used OC aerosol concentrations measured in surface air in the United States (IMPROVE network) as topdown constraints on sources, and found that current source inventories could be adjusted to within their accepted uncertainties in order to match the top-down constraints. However, Heald et al. [2005] found that the standard GEOS-Chem simulation underestimates OC aerosol concentrations measured from aircraft in Asian outflow (ACEAsia campaign) by $1-2$ orders of magnitude in the free troposphere. These measurements showed consistently high concentrations $\left(1-17 \mu \mathrm{g} \mathrm{C} \mathrm{m}^{-3}\right)$ that could have significant implications for aerosol radiative forcing of climate and intercontinental aerosol transport. The ITCT-2K4 campaign provided the opportunity to further test our understanding of the factors controlling OC aerosol in the free troposphere,

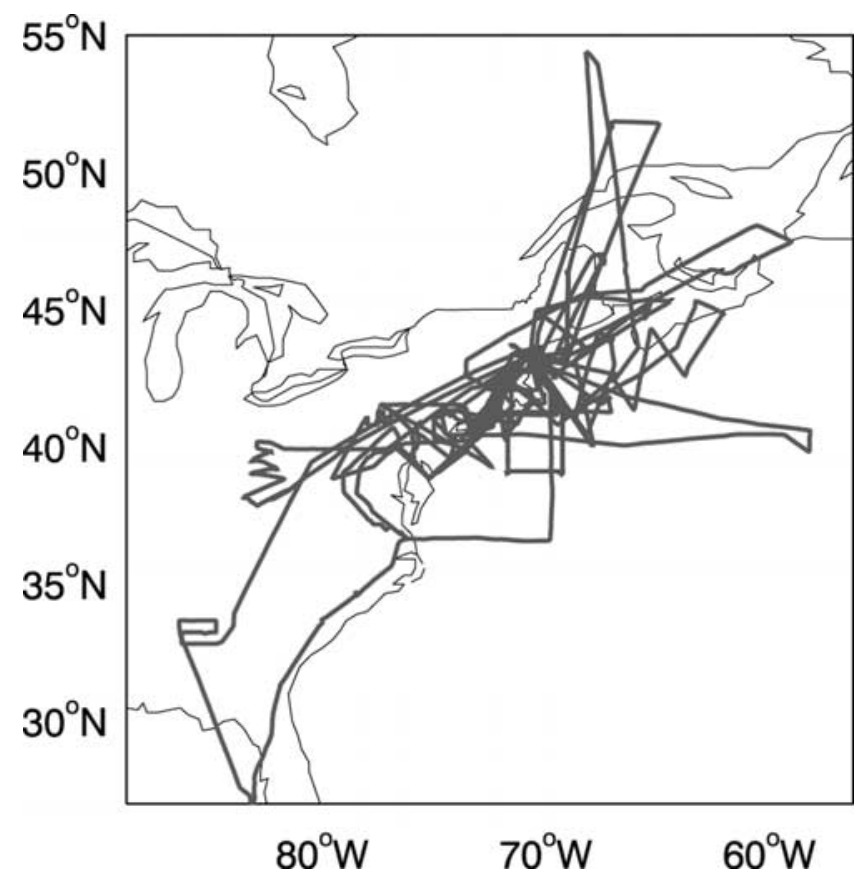

Figure 1. Flight tracks of the NOAA WP-3 aircraft up to $6 \mathrm{~km}$ altitude during the July-August 2004 ITCT-2K4 deployment.

in a far more extensive data set and including the link to the continental boundary layer (not accessible during ACE-Asia).

\section{Model Description}

[6] The GEOS-Chem global coupled oxidant-aerosol simulation for 2004 is driven by GEOS assimilated meteorological data from the NASA Global Modeling and Assimilation Office (GMAO). We employ here version 7.02.04 of GEOS-Chem (http://www-as.harvard.edu/ chemistry/trop/geos/index.html) driven by GEOS-4 meteorological fields including winds, convective mass fluxes, mixing depths, temperature, precipitation, and surface properties with $1^{\circ} \times 1.25^{\circ}$ horizontal resolution and 48 vertical layers. For input into GEOS-Chem we degrade the horizontal resolution of these meteorological fields to $2^{\circ} \times 2.5^{\circ}$. Applications of GEOS-Chem to interpretation of the ICARTT data are presented independently by C. R. Hudman et al. (Surface and lightning sources of nitrogen oxides in the United States: Magnitudes, chemical evolution and outflow, submitted to Journal of Geophysical Research, 2006; hereinafter referred to as Hudman et al., submitted manuscript, 2006) for ozone and nitrogen oxides, Turquety et al. (submitted manuscript, 2006) for CO, Millet et al. [2006] for formaldehyde, Y. Xiao et al. (Global budget of C2H6 and constraints on North American sources from ICARTT aircraft data, submitted to Journal of Geophysical Research, 2006) for acetylene, and Q. Liang et al. (Summertime influence of Asian pollution in the free troposphere over North America, submitted to Journal of Geophysical Research, 2006) for transpacific Asian pollution. We describe here the simulation for organic aerosols. The model is initialized with a 1-year simulation ending in June 2004. All 

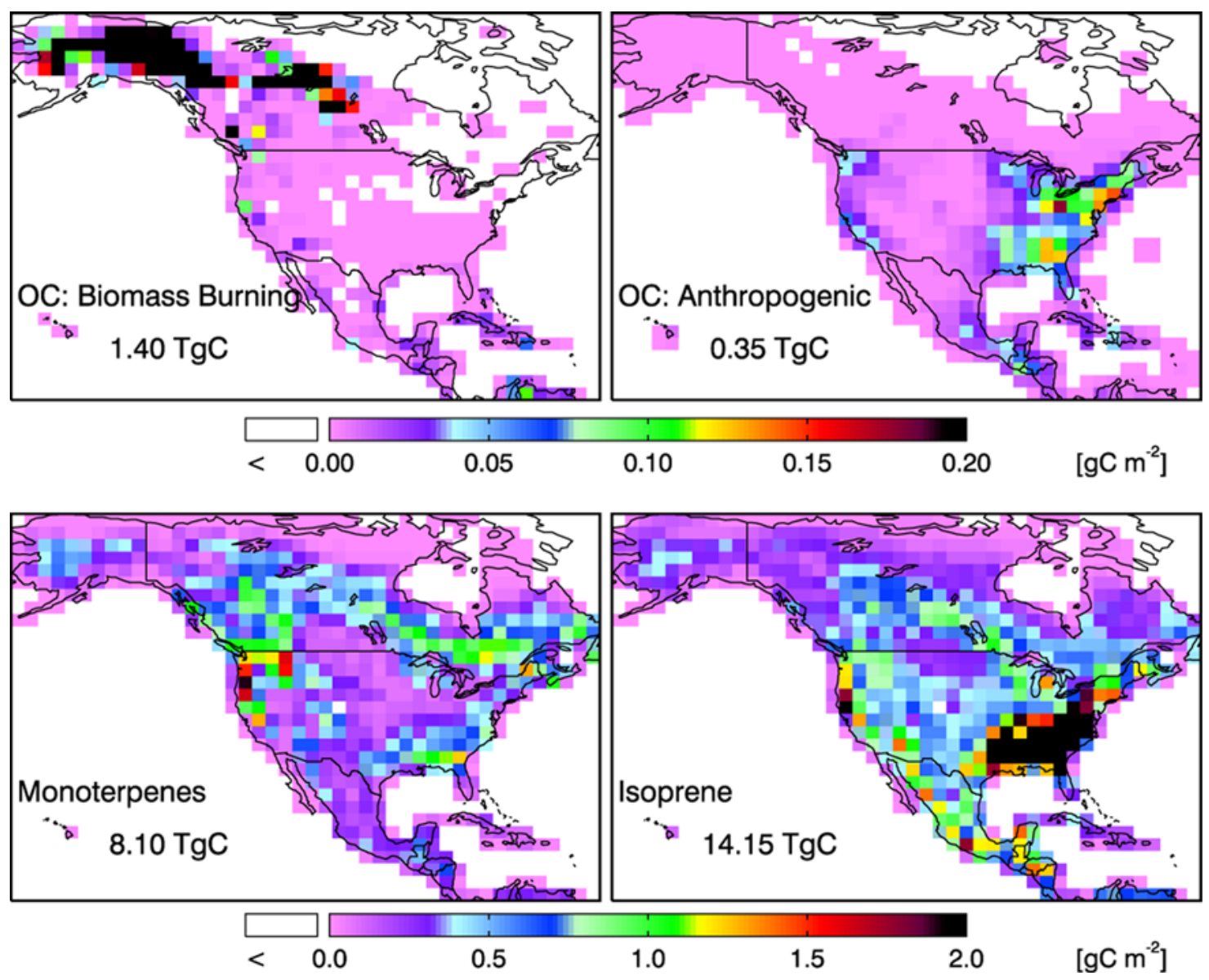

Figure 2. Emissions of organic carbon aerosol [Cooke et al., 1999] (Turquety et al., submitted manuscript, 2006) and biogenic secondary organic aerosol precursor emissions [Guenther et al., 1995 ]. Anthropogenic emissions include both fossil fuel and biofuel. Total emissions for the domain are shown in each panel. The color bars are saturated at $0.20 \mathrm{~g} \mathrm{C} \mathrm{m}^{-2}$ and $2.0 \mathrm{~g} \mathrm{C} \mathrm{m}^{-2}$.

sensitivity simulations are conducted for June-August 2004, with the first month used for initialization.

[7] A challenge in the simulation of the ICARTT period is to adequately describe the boreal fire influence. We use here a daily inventory of biomass burned with $1^{\circ} \times 1^{\circ}$ spatial resolution constructed by Turquety et al. (submitted manuscript, 2006) on the basis of fire reports and MODIS satellite hot spot detections (Figure 2). The OC aerosol emission factor is taken to be $9.7 \mathrm{~g}$ per $\mathrm{kg}$ dry matter as given by R. J. Park et al. (Influences of biomass burning on aerosol and ozone concentrations in surface air over the United States: A case study of boreal wildfires for the summer of 2004, submitted to Journal of Geophysical Research, 2006), which is the mean value for boreal fires given by Andreae and Merlet [2001] with an associated OC/ $\mathrm{CO}$ emission ratio of $0.10 \mathrm{~g} \mathrm{~g}^{-1}$ (equivalent to $0.23 \mathrm{~mol} \mathrm{C}$ $\mathrm{mol}^{-1}$ ). The resulting emissions over North America (domain of Figure 2) in July-August 2004 total 1.4 Tg C. A recent review by Reid et al. [2005] indicates a large range of smoke aerosol emission ratios from boreal fires, 7-60 g per kg dry matter; OC accounts for the bulk of the smoke aerosol.

[8] Pyroconvective events can inject biomass-burning emissions from boreal wildfires directly into the free troposphere [Fromm et al., 2000, 2005; Fromm and Servranckx,
2003]. Damoah et al. [2006] found that CO was lofted into the lower stratosphere during a particularly vigorous pyroconvective event associated with the 2004 Alaskan boreal fires in late June. Precipitation can be suppressed in pyroconvective systems due to the abundance of cloud condensation nuclei [Andreae et al., 2004], thereby delivering OC aerosol directly into the free troposphere without experiencing wet removal. The injection height of aerosols is critical in determining their long-range transport. The GEOS-Chem simulation used here injects $40 \%$ of boreal fire emissions in the boundary layer and $60 \%$ directly in the free troposphere $(3-5 \mathrm{~km})$ without scavenging. This is consistent with de Gouw et al. [2006] who found that it was necessary to inject the boreal fire emissions throughout the troposphere $(0-10 \mathrm{~km})$ to simulate the transport of acetonitrile during ITCT-2K4, and Turquety et al. (submitted manuscript, 2006) who found that the long-range transport of CO as seen from the MOPITT satellite instrument and the ICARTT aircraft observations could only be reproduced with free tropospheric injection of emissions.

[9] Anthropogenic emission from fuel combustion is a major source of OC aerosol in the United States [Park et al., 2003]. The most recent emission inventory for fossil fuel sources is from Bond et al. [2004], but comparison with wintertime OC aerosol concentrations in the United States 
suggests that it is a factor of 2 too low [Park et al., 2006]. We use instead the Cooke et al. [1999] inventory for fossil fuels with the seasonal cycle and $16 \%$ upward scaling of Park et al. [2003], who optimized OC aerosol emissions to match IMPROVE surface site observations in 1998. Biofuel emissions of OC aerosol (mostly from agroindustrial activities) are also taken from Park et al. [2003], who found that they dominate over fossil fuel. For July through August 2004, emissions of OC aerosol from anthropogenic sources in North America total $0.35 \mathrm{Tg} \mathrm{C}(0.26 \mathrm{Tg} \mathrm{C}$ from biofuels and 0.09 from fossil fuels) (Figure 2).

[10] The model includes secondary organic aerosol (SOA) formation from the oxidation of biogenic isoprene, terpenes, and other reactive volatile organic compounds (ORVOCs) following the approach of Chung and Seinfeld [2002] extended to isoprene by Henze and Seinfeld [2006]. This scheme allows semivolatile secondary organic gases (SOG) produced from VOC oxidation to partition reversibly into the aerosol phase as a function of temperature and preexisting OC aerosol volume. Biogenic VOC precursor emissions are from the GEIA inventory [Guenther et al., 1995] and are shown in Figure 2. The total source of terpenes and ORVOCs for North America in July-August is $8.1 \mathrm{Tg} \mathrm{C}$, and a typical $10 \%$ SOA yield (note though that production is reversible) implies a SOA source of $0.81 \mathrm{Tg}$ C. The total isoprene source for North America in JulyAugust of $14.2 \mathrm{Tg} \mathrm{C}$ in the GEIA inventory, and a typical $3 \%$ SOA yield [Kroll et al., 2005] implies a SOA source of $0.42 \mathrm{Tg} \mathrm{C}$, half of the terpene source.

[11] We do not include SOA production from aromatic anthropogenic VOCs, since the standard parameterization for this source based on SOG/SOA reversible partitioning [Odum et al., 1997] yields negligible concentrations outside urban areas [Chung and Seinfeld, 2002; Tsigaridis and Kanakidou, 2003]. We verified this for the ITCT-2K4 conditions using aromatic VOC emission inventories for the northeastern United States and available SOA yield data. This conclusion could change if new laboratory yield data were to show a significant increase in aromatic SOA production. Recent field observations [de Gouw et al., 2005; Zhang et al., 2005; Volkamer et al., 2006] suggest a larger anthropogenic contribution to SOA than from the above mechanism but the underlying processes are not understood.

[12] Loss of OC aerosol in the model is by wet and dry deposition, and in the case of SOA also by reversible volatilization. Dry deposition follows a standard resistance-in-series scheme as described by Wang et al. [1998] and Park et al. [2004]. Wet deposition is a more important sink and is applied to the hydrophilic component of the OC aerosol following the scheme of Liu et al. [2001] which includes in-cloud rainout and below cloud washout from convective anvils and large-scale precipitation, and scavenging in convective updrafts. Primary emissions of $\mathrm{OC}$ aerosol are assumed to be $50 \%$ hydrophobic and $50 \%$ hydrophilic with a 1.2 day e-folding conversion from hydrophobic to hydrophilic [Cooke et al., 1999; Park et $a l ., 2005]$. There was a high degree of internal mixing in the aerosol particles sampled during ITCT-2K4 [Murphy et al., 2006], implying that the OC aerosol is predominantly hydrophilic. We assume that $80 \%$ of the SOA is hydrophilic following Chung and Seinfeld [2002]. This fraction repre- sents the scavenging efficiency of dicarboxylic acids as determined by Limbeck and Puxbaum [2000], who report a range of 16 to $98 \%$ for a variety of polar organic compounds. The solubility of the SOG compounds in equilibrium with SOA is very uncertain. Chung and Seinfeld [2002] use a Henry's Law coefficient for SOGs of $10^{5} \mathrm{M}$ $\mathrm{atm}^{-1}$ as a median value within the range given by R. Sander (Compilation of Henry's law constants for inorganic and organic species of potential importance in environmental chemistry (version 3), 1999, available at http://www.mpch-mainz.mpg.de/ sander/res/henry.html) of $10^{3} \mathrm{M} \mathrm{atm}^{-1}$ for carboxylic acids and $10^{6}-10^{8} \mathrm{M} \mathrm{atm}^{-1}$ for dicarboxylic acids. We use that value in our standard simulation. Henze and Seinfeld [2006] found that simulated SOA concentrations increased by up to $60 \%$ in the free troposphere when the solubility of SOG is decreased to $10^{4} \mathrm{M} \mathrm{atm}^{-1}$.

\section{Observations of Organic Carbon Aerosol in Summer 2004}

[13] Figure 3 shows the geographical distribution of gridded $\left(2^{\circ} \times 2.5^{\circ}\right)$ OC aerosol observations at the IMPROVE surface sites and aboard the ITCT-2K4 aircraft during July-August 2004. Here and elsewhere, all concentrations are expressed as $\mu \mathrm{g} \mathrm{C} \mathrm{m}^{-3}$ at standard conditions of temperature and pressure (STP); $1 \mu \mathrm{g} \mathrm{C} \mathrm{m}^{-3}=2.02 \mathrm{ppb}$. WSOC aerosol $(<1 \mu \mathrm{m}$ in diameter) was measured aboard the aircraft with a detection limit of $0.1 \mu \mathrm{g} \mathrm{C} \mathrm{m}^{-3}$ [Sullivan et al., 2006]. A carbon parallel plate denuder was used to eliminate artifacts from gas-phase organics [Sullivan et al., 2006]. The IMPROVE network of surface sites, which monitors visibility in wilderness areas in the United States [Malm et al., 1994], reports 24-hour averages of surface concentrations of OC aerosol every third day. Total $\mathrm{OC}$ aerosol concentrations consist of four components pyrolyzed from the filter samples at different temperatures. Detection limits generally range from 0.05 to $0.20 \mu \mathrm{g} \mathrm{C} \mathrm{m}^{-3}$ for each OC component. Concentrations may be underestimated due to evaporation from filter samples, particularly in summer [Malm et al., 1994].

[14] The average surface concentration of OC aerosol at the 37 IMPROVE sites over the ITCT-2K4 flight domain (defined by Figure 3) was $2.1 \mu \mathrm{g} \mathrm{C} \mathrm{m}^{-3}$. As shown in Figure 3 , these concentrations are consistent with the boundary layer WSOC concentrations measured by the aircraft, which averaged $2.3 \mu \mathrm{g} \mathrm{C} \mathrm{m}^{-3}$. This suggests, barring measurement artifacts, that OC aerosol in the boundary layer is mostly water-soluble. The IMPROVE data show less spatial variability than the aircraft data, reflecting the generally remote character of the sites vs. the variety of air masses sampled by the aircraft including urban plumes.

[15] Mean WSOC concentrations observed above the boundary layer $(2-6 \mathrm{~km})$ range from 0.2 to $8.5 \mu \mathrm{g} \mathrm{C} \mathrm{m}^{-3}$ on the $2^{\circ} \times 2.5^{\circ}$ grid (Figure 3c), with individual 1-min observations of up to $26 \mu \mathrm{g} \mathrm{Cm}^{-3}$. The average is $1.7 \mu \mathrm{g} \mathrm{C} \mathrm{m} \mathrm{m}^{-3}$.

[16] The highest WSOC aerosol concentrations in the ITCT-2K4 data are in biomass-burning plumes from the boreal fires in Alaska and NW Canada [Sullivan et al., 2006]. To filter these plumes from the data set we use observations of acetonitrile $\left(\mathrm{CH}_{3} \mathrm{CN}\right)>225 \mathrm{ppt}$ as a tracer 
a) IMPROVE (Surface)

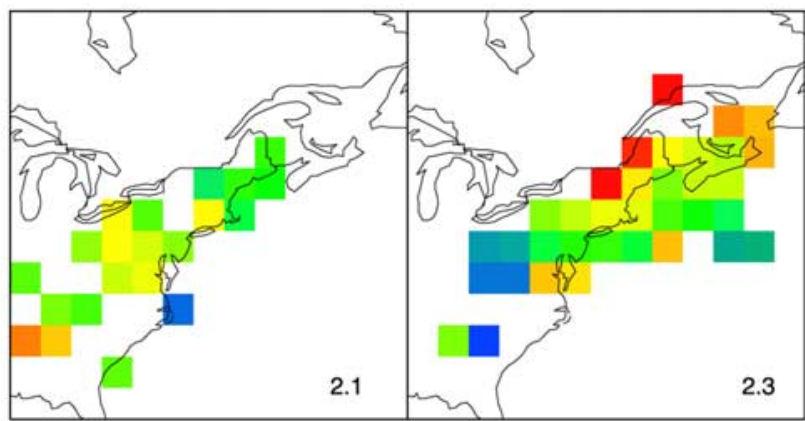

c) ITCT-2K4 (2-6 km)
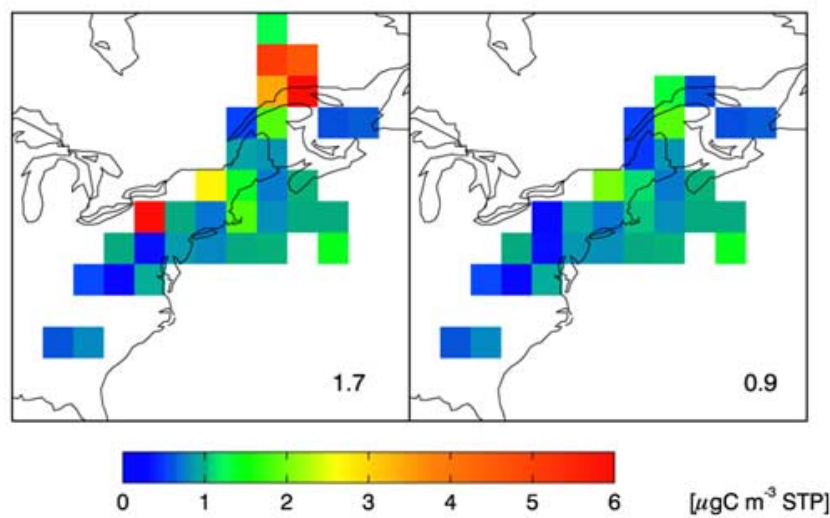

Figure 3. Mean gridded $\left(2^{\circ} \times 2.5^{\circ}\right)$ concentrations of organic carbon (OC) aerosol observed over northeastern North America in July-August 2004 in mixing ratio units of $\mu \mathrm{g} \mathrm{C} \mathrm{m} \mathrm{g} \mathrm{m}^{-3}$ standard conditions of temperature and pressure (STP). (a) OC aerosol measurements at IMPROVE surface sites; (b) ITCT-2K4 aircraft observations of watersoluble organic carbon (WSOC) aerosol in the boundary layer $(0-2 \mathrm{~km})$; (c) ITCT-2K4 aircraft observations of WSOC in the free troposphere $(2-6 \mathrm{~km})$; (d) ITCT-2K4 aircraft observations of WSOC in the free troposphere filtered to remove biomass-burning plumes as described in section 3. Mean values are shown in each panel. The color bar is saturated at $6.0 \mu \mathrm{g} \mathrm{C} \mathrm{m}^{-3}$.

of biomass burning [Holzinger et al., 1999]. Acetonitrile is emitted by biomass burning but not significantly by fossil fuel combustion [Singh et al., 2003]. Figure 4a shows how this filter targets the high tail of the observed WSOC aerosol distribution in the free troposphere $(2-6 \mathrm{~km})$. Fire plumes make up $9 \%$ of the observations in the free troposphere, and are discussed further by de Gouw et al. [2006]. Mean filtered concentrations of WSOC aerosol in the free troposphere average $0.9 \mu \mathrm{g} \mathrm{C} \mathrm{m}^{-3}$ and do not exceed $2.0 \mu \mathrm{g} \mathrm{C} \mathrm{m}^{-3}$ on the $2^{\circ} \times 2.5^{\circ}$ grid (Figure $3 \mathrm{~d}$ ). The filtered data set shows no correlation with $\mathrm{CH}_{3} \mathrm{CN}(R=0.01)$, suggesting that fire influences did not dictate the OC aerosol variability outside of the plumes.

[17] Figure 5 shows the vertical structure of the observed acetonitrile and WSOC aerosol concentrations. Acetonitrile concentrations peak in the lower free troposphere $(3-4 \mathrm{~km})$ and WSOC aerosol concentrations are correspondingly elevated in this region. Removing the fire plumes reduces the mean observed WSOC aerosol concentrations in the free troposphere by almost a factor of 2. By contrast, the contribution of fire plumes to observed WSOC aerosol in the boundary layer is small.

[18] The filtered concentrations of WSOC aerosol observed during ITCT-2K4 in the free troposphere over North America (mean of $0.9 \pm 0.9 \mu \mathrm{g} \mathrm{C} \mathrm{m}^{-3}$ ) are significantly smaller than the OC aerosol concentrations observed in the free troposphere over the NW Pacific during the ACE-Asia aircraft campaign based in southern Japan (mean of $3.3 \pm$ $2.8 \mu \mathrm{g} \mathrm{C} \mathrm{m}^{-3}$ ) [Heald et al., 2005]. The weak vertical gradient between the boundary layer and free troposphere observed in ACE-Asia suggested a SOA source in the free troposphere. In contrast, the filtered WSOC aerosol in ITCT-2K4 decreases from the surface to the free troposphere by over a factor of 2 (Figure 5). This likely reflects the sampling of the continental boundary layer by the ITCT$2 \mathrm{~K} 4$ aircraft versus the marine boundary layer in ACE-Asia. However, as discussed below, it does not appear that aerosol transport from the continental boundary layer could have been a major source of the free tropospheric WSOC aerosol observed in ITCT-2K4.

\section{Source Attribution}

[19] We use here the GEOS-Chem simulation as described in section 2 to interpret the WSOC aerosol concentrations observed during ITCT-2K4 in terms of contributing sources. We compare the measurements of WSOC aerosol with the sum of the simulated hydrophilic primary OC aerosol and $80 \%$ of the simulated SOA (consistent with our scavenging assumptions as described in section 2). Not all of the hydrophilic primary OC may in fact be watersoluble, in which case the model WSOC would be an upper limit. We determined the source contributions to the simulated WSOC as follows. The difference between our base case and a simulation with no biomass-burning emissions defines the biomass-burning contribution. The anthropogenic OC aerosol is determined as the remaining fraction of primary OC. The SOA concentrations are determined from the base case simulation including primary biomass burning and anthropogenic OC aerosol to serve as condensation sites.

\subsection{Biomass-Burning Plumes and Emission Ratio}

[20] Figure $4 \mathrm{~b}$ shows the probability distributions of simulated free tropospheric WSOC concentrations along the ITCT-2K4 aircraft tracks, for the complete data set and the filtered data set with biomass-burning plume observation periods excluded. The biomass-burning filter based on observed acetonitrile (section 3) identifies just two model plumes. Outside of these plumes, the simulated WSOC aerosol concentrations are lognormally distributed, similar to observations. The paucity of model plumes is to be expected in view of the averaging of source and transport processes intrinsic in a global Eulerian model such as GEOS-Chem.

[21] We can use the observed and model plumes to evaluate the fire $\mathrm{OC} / \mathrm{CO}$ emission ratio of $0.23 \mathrm{~mol} \mathrm{C} \mathrm{mol}^{-1}$ used in the model. Figure 6 shows the WSOC-CO relationship observed in free tropospheric biomass-burning plumes (diagnosed by $\mathrm{CH}_{3} \mathrm{CN}>225 \mathrm{ppt}$ ) and in the 
a) Observed

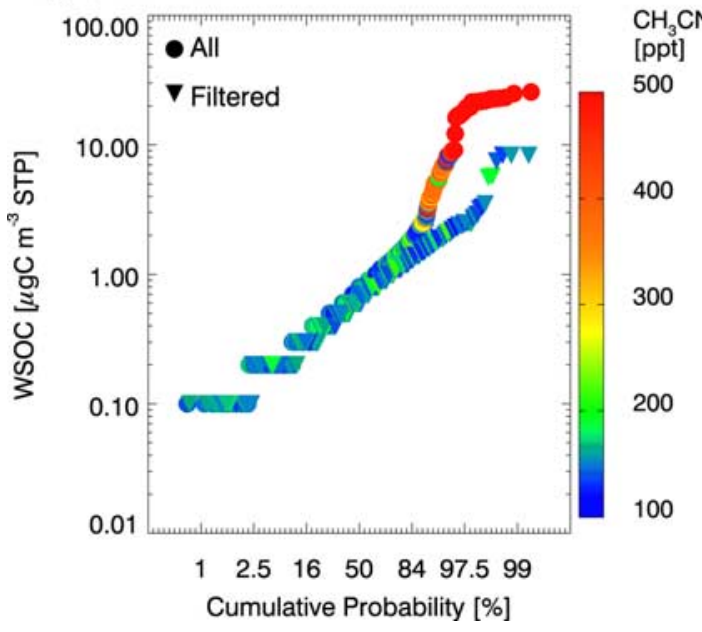

b) Simulated

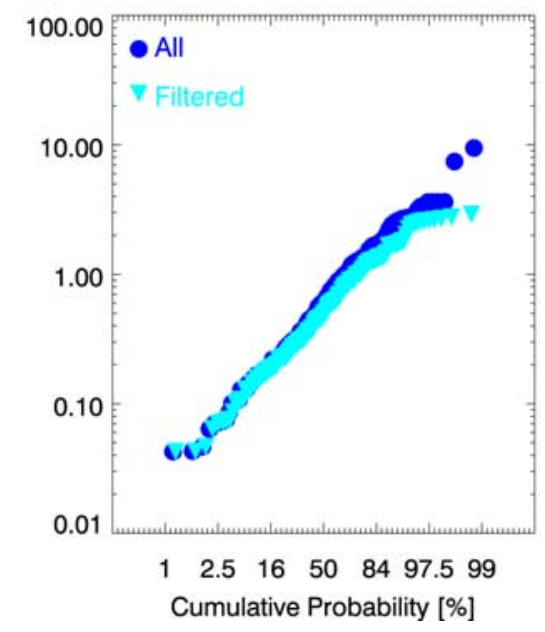

Figure 4. Cumulative probability distributions of water-soluble organic carbon (WSOC) aerosol concentrations in the free troposphere $(2-6 \mathrm{~km})$ along the ITCT-2K4 aircraft tracks: (a) 1-min average observations with detection limit of $0.1 \mu \mathrm{g} \mathrm{C} \mathrm{m}^{-3}$ [Sullivan et al., 2006] and (b) the corresponding gridded $\left(2^{\circ} \times 2.5^{\circ}\right)$ concentrations simulated by the GEOS-Chem model. Complete distributions are shown as circles, and the subsets filtered to remove biomass-burning plumes (as diagnosed by $\mathrm{CH}_{3} \mathrm{CN}>$ $225 \mathrm{ppt}$ ) are shown as triangles. The observed distribution is colored by the observed concentration of $\mathrm{CH}_{3} \mathrm{CN}$. The color scale is saturated at 500 ppt. The GEOS-Chem model simulation is sampled at the time and location of the aircraft flights, and the WSOC aerosol concentrations are reported at STP conditions. The abscissa is a normal probability scale, and the ordinate is a log scale, such that a lognormal distribution would plot as a

corresponding model plumes. The GEOS-Chem simulation of $\mathrm{CO}$ is described by Turquety et al. (submitted manuscript, 2006). The observed enhancement ratio from linear regression (reduced major axis method) is $\mathrm{dWSOC} / \mathrm{dCO}=$ $0.14 \mathrm{~mol} \mathrm{C} \mathrm{mol}^{-1}$ (Figure 6). This is $40 \%$ lower than the emission ratio used in the model (dotted line in Figure 6). However, the dWSOC/dCO enhancement ratio in the two model plumes is consistent with observations (Figure 6), suggesting that the observed enhancement ratio is in fact consistent with the model emission ratio. Decrease in $\mathrm{dWSOC} / \mathrm{dCO}$ from the point of fire emission to the point of sampling could reflect dilution with a nonzero background CO [McKeen et al., 1996] or aerosol scavenging, or both. Dilution with anthropogenic air masses over northeastern North America, for which the emission ratio is $0.043 \mathrm{~mol} \mathrm{C} \mathrm{mol}^{-1}$, would also contribute to this decrease in $\mathrm{dWSOC} / \mathrm{dCO}$.

[22] The spread in the observed WSOC/CO relationship in fire plumes (Figure 6) may reflect variable emission ratios under different burn conditions [Reid et al., 2005] or different histories of aerosol scavenging. De Gouw et al. [2006] found an association between low aerosol enhancement and low dew point (indicative of precipitation history) for one of the ITCT-2K4 fire plumes. However, we do not find that the general spread in the WSOC-CO relationship in Figure 6 is correlated with dew point.

\subsection{Boundary Layer}

[23] Figure 7a shows the surface OC aerosol concentrations simulated by the model at the IMPROVE sites in July-August 2004. The model is 30\% too low on average and does not capture the observed spatial variability $(R=$

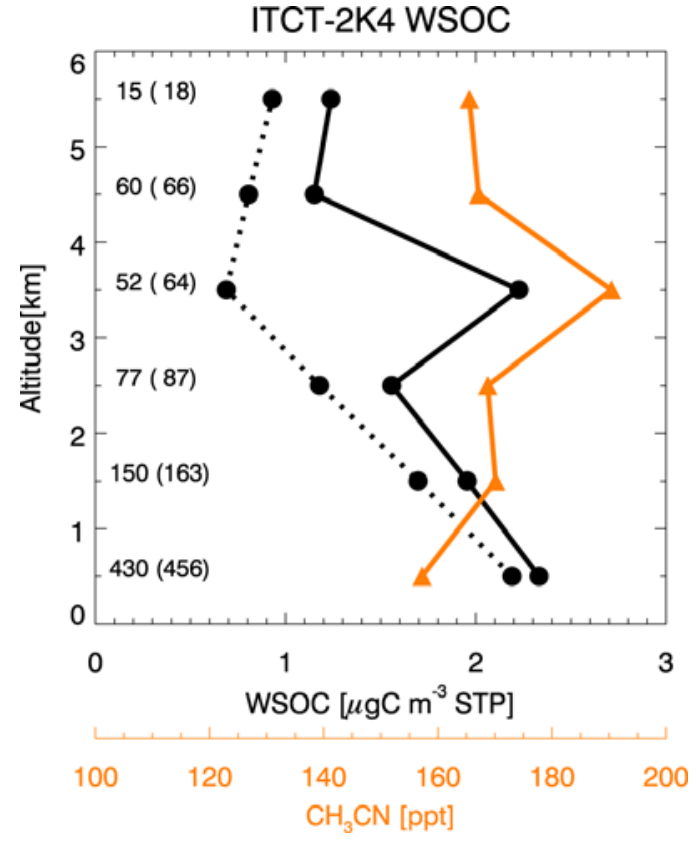

Figure 5. Mean vertical profiles of observed water-soluble organic carbon aerosol (WSOC, black circles) and acetonitrile $\left(\mathrm{CH}_{3} \mathrm{CN}\right.$, orange triangles) for all the ITCT-2K4 flights (solid line). The mean WSOC profile when biomassburning plumes are filtered (as described in section 3 ) is shown as the dotted line. Concentrations are reported at standard temperature and pressure conditions and are gridded to $2^{\circ} \times 2.5^{\circ}$ horizontal resolution. The number of observations in each altitude bin is given on the left of the figure, with the total number of filtered observations given in parentheses. 


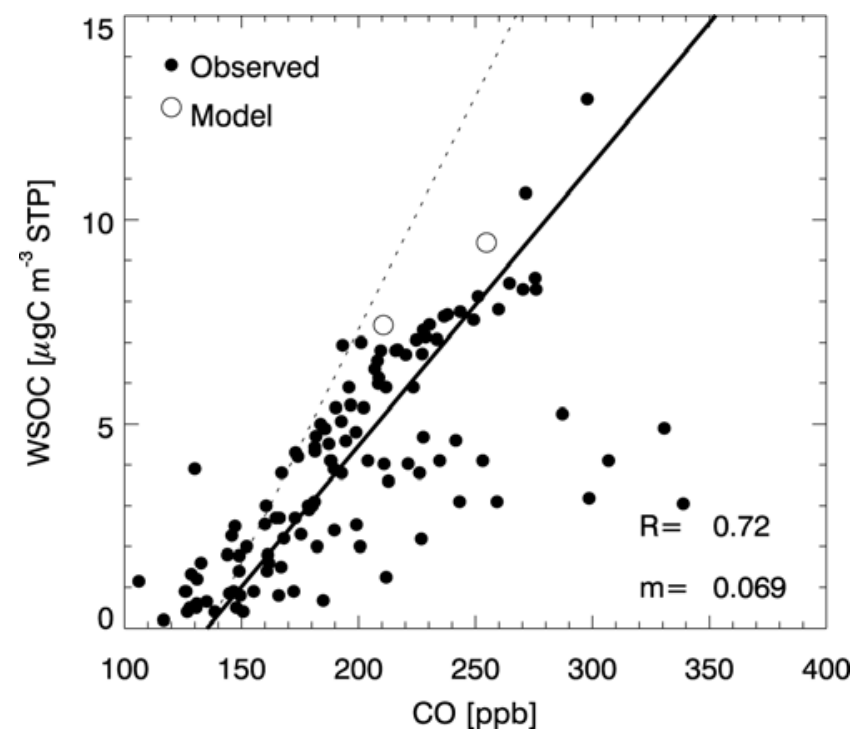

Figure 6. Relationship between observed water-soluble organic carbon (WSOC) aerosol and CO concentrations in biomass-burning plumes sampled during ITCT-2K4 (black circles, with regression line (solid) computed by the reduced major axis method [Hirsch and Gilroy, 1984]). The correlation coefficient is $R=0.72$, and the slope is $m=$ $0.069 \mu \mathrm{g} \mathrm{C} \mathrm{m}^{-3}$ STP (ppb CO) $)^{-1}=0.14 \mathrm{~mol} \mathrm{C} \mathrm{mol}^{-1}$. Biomass-burning plumes were selected as observations with acetonitrile $>225$ ppt. The two simulated GEOS-Chem fire plumes (Figure 4b) are shown as hollow circles. The dotted line shows the boreal fire $\mathrm{OC} / \mathrm{CO}$ emission ratio from Andreae and Merlet [2001] used in the model. The CO simulation is from Turquety et al. (submitted manuscript, 2006).

0.33). The previous GEOS-Chem simulation of 2001 national IMPROVE data by Park et al. [2006] found no significant bias, and higher concentrations in the northeast than found here. We find that this reflects differences in precipitation frequency between the two simulations, likely due to differences in the assimilated meteorological data systems used (GEOS-3 for 2001, GEOS-4 for 2004). The IMPROVE observations show no significant difference between 2001 and 2004 over the northeastern United States.

[24] We find that simulated surface concentrations in the northeastern United States for the ICARTT period (Figure 7a) include contributions from anthropogenic (49\%), biomass burning (27\%) and biogenic (24\%) sources. Isoprene oxidation contributes on average one third of the total simulated SOA, with the reminder contributed by terpenes and ORVOCs. Correlation of WSOC with $\mathrm{CO}$ $(R=0.72)$ is found in the observations [Sullivan et al., 2006], and also in the model $(R=0.78)$ but the dWSOC/ dCO slope in the model is a factor of 2 lower than observed ( 0.040 vs. $0.074 \mathrm{~mol} \mathrm{C} \mathrm{mol}^{-1}$ ). This could suggest a missing anthropogenic source, possibly secondary [Sullivan et al., 2006]. However, we also find in the model that biogenic SOA and CO are correlated $(R=0.57)$, and an increase in simulated biogenic SOA by a factor of 4 would similarly correct the underestimate of the dWSOC/dCO slope $(R=$ $0.69)$. The observed WSOC-CO relationship thus does not point unambiguously to an anthropogenic source.

\subsection{Free Troposphere}

[25] Figure 8 compares the mean vertical profile of observed WSOC aerosol concentrations (spatial patterns shown in Figure $7 \mathrm{~b}$ ), filtered to remove biomass-burning plumes as described in section 3, with the GEOS-Chem model simulation along the flight tracks similarly filtered for the times and location of the observed biomass-burning plumes. Also shown are the simulated versus observed vertical profiles of total sulfur oxides $\left(\mathrm{SO}_{\mathrm{x}} \equiv\right.$ sulfate + $\mathrm{SO}_{2}$ ), which we use as a test of scavenging of soluble species in the model during transport from the boundary layer to the free troposphere [Park et al., 2005; Heald et al., 2005]. As seen in the figure, this scavenging is well simulated by the model. Removal of soluble aerosols during lifting effectively disconnects free tropospheric concentrations from the boundary layer. Observed total $\mathrm{SO}_{\mathrm{x}}$ (and sulfate, not shown) concentrations decrease by a factor of 10 from the surface to $6 \mathrm{~km}$ altitude, whereas observed WSOC aerosol concentrations decrease by only a factor of 2. This suggests that the WSOC aerosol observed above $2 \mathrm{~km}$ is not transported from the boundary layer. Concentrations of WSOC aerosol in the free troposphere $(2-6 \mathrm{~km})$ are underestimated in the model by $25 \%$ on average, as compared to the factor of $10-100$ underestimate found during the ACE-Asia campaign in the free troposphere [Heald et al., 2005]. As shown in section 3, mean free tropospheric concentrations of organic carbon aerosol were 4 times lower during ITCT-2K4 than ACE-Asia. In addition, mean simulated concentrations of WSOC aerosol in the free troposphere over North America $\left(0.7 \pm 0.6 \mu \mathrm{g} \mathrm{C} \mathrm{m}^{-3}\right)$ are more than twice the $\mathrm{OC}$ aerosol simulated during ACE-Asia $\left(0.3 \pm 0.2 \mu \mathrm{g} \mathrm{C} \mathrm{m}^{-3}\right)$. WSOC accounts for the bulk of free tropospheric OC aerosol in the model (Figure 8b). Comparison with ACE-Asia data is discussed further in section 6 .

a) GEOS-Chem (Surface)
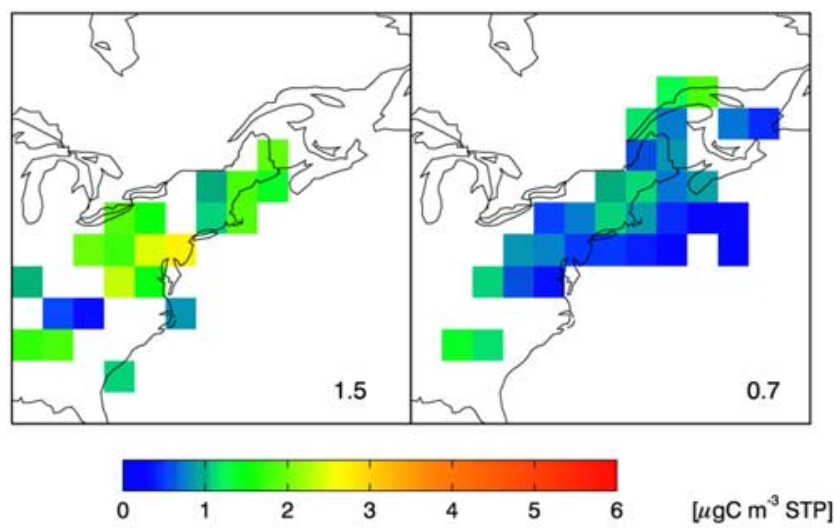

Figure 7. Mean gridded $\left(2^{\circ} \times 2.5^{\circ}\right)$ concentrations of organic carbon aerosol simulated over northeastern North America in July-August 2004 in mixing ratio units of $\mu \mathrm{g} \mathrm{C}$ $\mathrm{m}^{-3}$ STP. (a) Twenty-four-hour values simulated at IMPROVE surface sites. (b) Simulated WSOC aerosol concentrations along ITCT-2K4 aircraft flight tracks in the free troposphere $(2-6 \mathrm{~km})$ filtered to remove biomassburning plumes as described in section 3. Mean values are shown in each panel. The color bar is the same as in Figure 3. 
a) ITCT-2K4 $\mathrm{SO}_{x}$

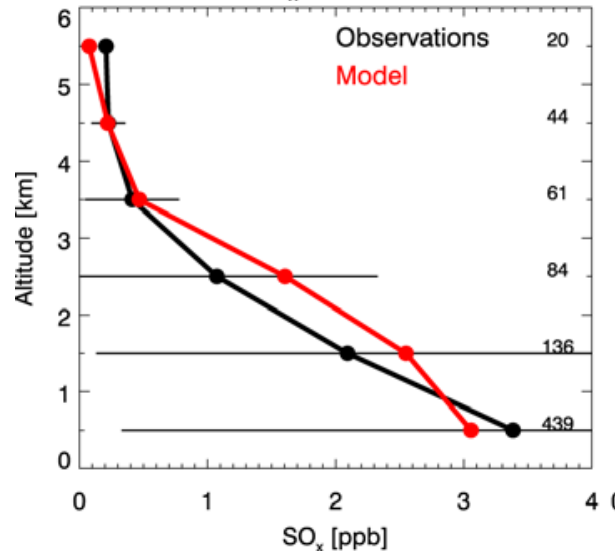

b) ITCT-2K4 WSOC

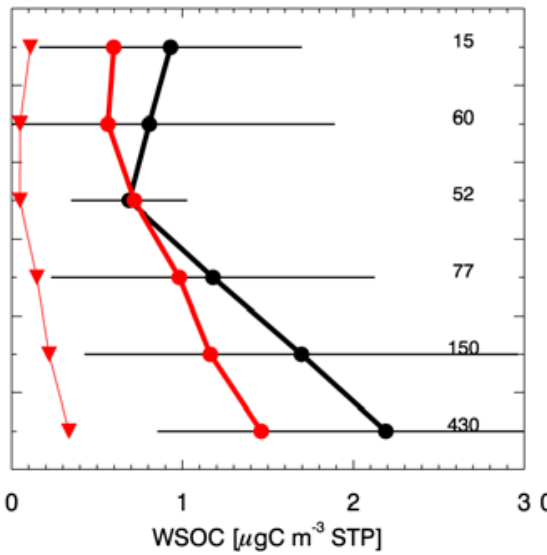

c) Simulated ITCT-2K4 OC

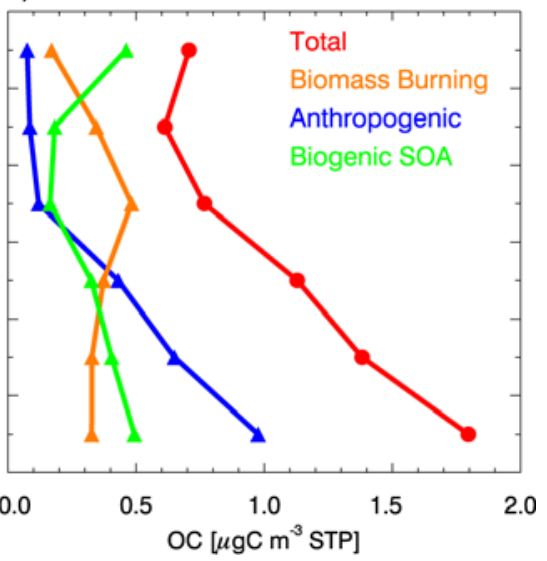

Figure 8. Mean vertical profiles of (a) sulfur oxides $\left(\mathrm{SO}_{\mathrm{x}} \equiv \mathrm{SO}_{2}+\right.$ sulfate) and (b) water-soluble organic carbon aerosol (WSOC) as observed (solid black) and simulated by the GEOS-Chem model (thick red line) for the filtered ITCT-2K4 data with biomass-burning plumes removed (as described in section 3). Simulated hydrophobic OC aerosol (not included in WSOC) is also shown in Figure 8b as a thin red line (inverted triangles). (c) Contributions to total (red line) simulated OC aerosol from biomassburning (orange line), anthropogenic (blue line), and biogenic (green line) sources. The GEOS-Chem model simulation is sampled at the time and location of the aircraft flights, and the observations are averaged to the model resolution. The standard deviation of the observations in each altitude bin is shown as an error bar with the number of observations in each bin given on the right of the figure.

[26] Figure 8c shows the source contributions to the simulated OC aerosol along the ITCT-2K4 flight tracks. Biomass burning and biogenic sources dominate in the free troposphere, in contrast to the boundary layer where the principal source is anthropogenic. Fresh anthropogenic emissions include a 50\% hydrophobic fraction, but the 1.2 e-folding timescale for conversion of hydrophobic to hydrophilic aerosols in the model is much shorter than the $\sim 5$ day timescale for boundary layer ventilation [ $L i$ et al., 2005]. The anthropogenic contribution therefore declines considerably from the boundary layer to the free troposphere, reflecting efficient scavenging in the model and consistent with the $\mathrm{SO}_{\mathrm{x}}$ vertical profile. This scavenging affects less the biomass-burning source, $60 \%$ of which is injected directly in the free troposphere in the model, and the biogenic source, for which the scavenging effect is compensated by lower temperature driving partitioning of SOG into the aerosol.

[27] Boreal fires emissions in the model account for $42 \%$ of total OC aerosol in the free troposphere outside of fire plumes. This contribution comes from the mixing of fire emissions with background air over North America and is sensitive to the assumed injection height. Simulated biomass-burning influence peaks at $3-4 \mathrm{~km}$ altitude, reflecting the preferential altitude for injection of fire emissions (section 2). We conducted a sensitivity simulation with all biomass-burning emissions released in the boundary layer and found a factor of 2 decrease in the simulated biomass-burning $\mathrm{OC}$ aerosol concentrations in the free troposphere.

[28] Mean simulated SOA concentrations in the free troposphere range from 0.2 to $0.5 \mu \mathrm{g} \mathrm{C} \mathrm{m}^{-3}$ during ITCT-2K4 and account for $36 \%$ of the total OC aerosol on average. Our previous simulation for the spring of 2001 ACE-Asia campaign using the same scheme (though with- out isoprene as a precursor) [Heald et al., 2005] indicated much lower concentrations, averaging $0.03 \mu \mathrm{g} \mathrm{C} \mathrm{m}^{-3}$. The higher SOA for the ITCT-2K4 conditions reflects the high biogenic VOC emissions from North America in summer. We see from the vertical profile in Figure 8c that SOA formation in the model is favored in the boundary layer where there is greater preexisting aerosol mass to act as a condensation surface and at the colder temperatures of the upper troposphere. SOA from isoprene contributes $15-30 \%$ of the simulated SOA during ITCT-2K4, making only a small contribution to total OC aerosol. Dicarbonyl oxidation and polymerization in clouds [Lim et al., 2005] could lead to a higher source of SOA from isoprene than simulated here.

[29] As discussed in section 2, the solubility of SOG is highly uncertain. We conducted a simulation with an assumed solubility of $10^{3} \mathrm{M} \mathrm{atm}^{-1}$ and found that mean simulated free tropospheric SOA concentrations in Figure 8 increased by $45 \%$ over the standard case $\left(10^{5} \mathrm{M} \mathrm{atm}^{-1}\right)$. The corresponding increase in total WSOC aerosol concentrations was less than $0.1 \mu \mathrm{g} \mathrm{C} \mathrm{m}^{-3}$.

\section{Correlations With Chemical Variables}

[30] Although the GEOS-Chem simulation reproduces the mean magnitude, range of concentrations (Figure 4) and vertical structure (Figure 8) of WSOC aerosol concentrations in the free troposphere observed during ITCT-2K4, it does not reproduce the variance in the individual observations. We find a correlation coefficient $R$ of only 0.21 between individual observations on the $2^{\circ} \times 2.5^{\circ}$ model grid, from $2-6 \mathrm{~km}$ in the filtered data set (excluding fire plumes) and corresponding model values. This suggests that the actual mechanisms controlling $\mathrm{OC}$ aerosol formation and loss are not properly described by the model. A large 


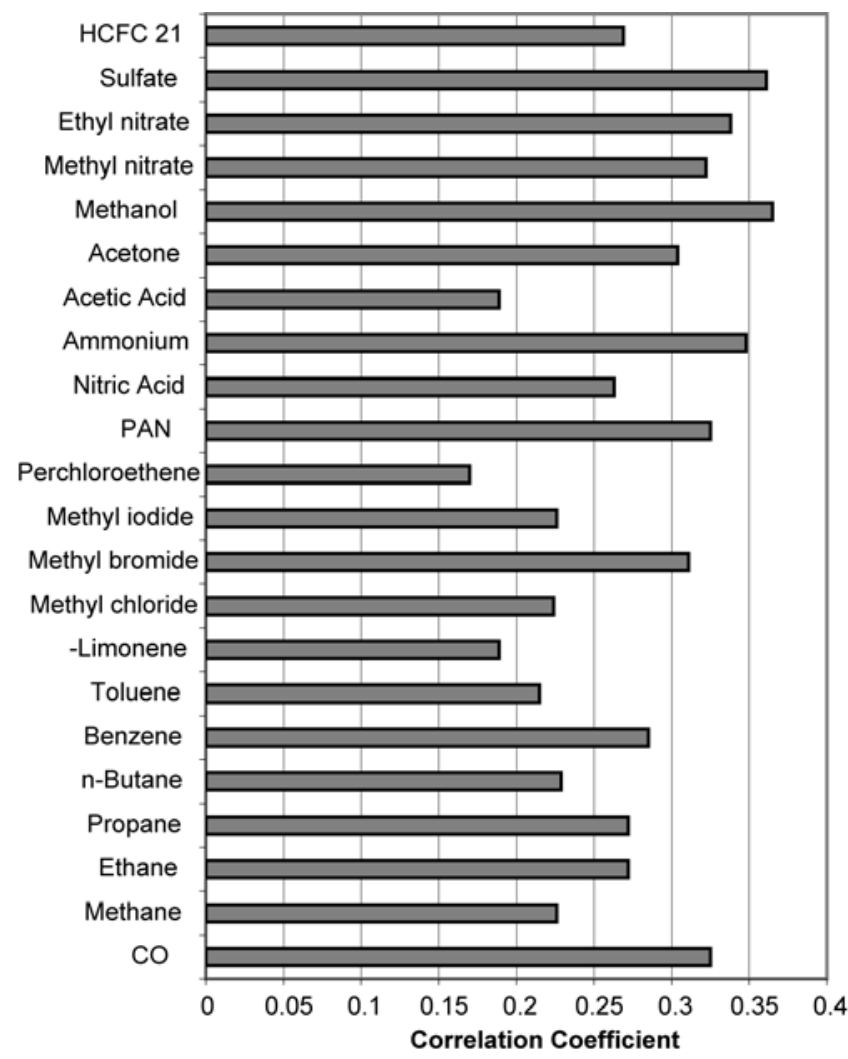

Figure 9. Correlation coefficients between water-soluble organic carbon (WSOC) aerosol and other chemical variables in ITCT-2K4 observations for the free troposphere $(2-6 \mathrm{~km})$ and for the filtered data set excluding fire plumes (section 3). Only selected species with more than 100 coincident observations and correlation coefficients $(R)$ significant at the $95 \%$ level are shown.

number of chemical variables were measured aboard the WP-3 aircraft together with WSOC aerosol, and we examine here the observed covariances of WSOC aerosol with these variables to gain further insight on $\mathrm{OC}$ aerosol sources in the free troposphere. We conduct the analysis for the 1-min average filtered data set at 2-6 km excluding biomass-burning plumes (section 3) and for 89 variables including a suite of VOCs [Schauffler et al., 1999; de Gouw et al., 2006], ozone and nitrogen oxides [Ryerson et al., 1998, 1999, 2000], CO and $\mathrm{SO}_{2}$ [Holloway et al., 2000], sulfate and ammonium aerosol [Weber et al., 2001], PAN, nitric acid, and ammonia [Slusher et al., 2004; Neuman et al., 2002; Nowak et al., 2007]. Although the free troposphere represents a wide range of sampling conditions, we find that within the $2-6 \mathrm{~km}$ domain there is no significant correlation between observed WSOC aerosol and temperature, relative humidity, pressure, or latitude. Therefore we consider the ensemble of 2-6 km observations as a single population for the purpose of correlation analysis.

[31] Figure 9 shows the correlation coefficients significant at the $95 \%$ level (with at least 100 coincident observations) for selected species (we verified that none of these correlations are driven by outliers). No chemical variables showed significant negative correlations with WSOC aero- sol. The strongest WSOC aerosol correlations $(R>0.35)$ are with sulfate and methanol. None of the biogenic SOA precursor gases (sesquiterpenes, monoterpenes, isoprene), nor their oxidation products (methylvinylketone or methacrolein) are significantly correlated with WSOC aerosol, with the exception of limonene $(R=0.19)$. We also find no significant correlation with $\mathrm{CH}_{3} \mathrm{CN}$, indicating that biomass burning is not a major source of WSOC aerosol variability outside of plumes. We used multivariate analysis to further resolve the WSOC aerosol variability. These indicate methanol to be the most successful predictor in combination with sulfate $(R=0.54)$, nitric acid $(R=0.53)$ or toluene $(R=$ $0.53)$. Methanol can be regarded as a long-lived tracer of terrestrial biogenic emissions [Jacob et al., 2005]. The sulfate and methanol predictors would be consistent with an aqueous-phase mechanism for SOA formation from the oxidation of biogenic VOCs, as suggested by Lim et al. [2005] and Carlton et al. [2006]. This process could take place in fair weather cumuli venting to the free troposphere [Parrish et al., 2004], which was also identified in ICARTT as a major source of nitric acid to the free troposphere (Hudman et al., submitted manuscript, 2006). Partitioning of SOA on inorganic aerosols may also contribute to the correlation of WSOC with sulfate and nitric acid. Correlation with toluene suggests an anthropogenic contribution to the free tropospheric SOA.

\section{Conclusions}

[32] We have used a global 3-D chemical transport model (GEOS-Chem) to interpret observations by Sullivan et al. [2006] of water-soluble organic carbon (WSOC) aerosol mass concentrations in the free troposphere $(2-6 \mathrm{~km})$ over northeastern North America during the ITCT-2K4 aircraft campaign of July-August 2004. We had previously found that the same model, including standard representations of primary and biogenic secondary sources, underestimated by a factor of 10-100 the free tropospheric OC aerosol concentrations observed over the NW Pacific off the coast of Japan (ACE-Asia aircraft campaign in April-May 2001) [Heald et al., 2005]. The ACE-Asia observations, averaging $3.3 \pm 2.8 \mu \mathrm{g} \mathrm{C} \mathrm{m}^{-3}$ at $2-6 \mathrm{~km}$, were the first measurements of $\mathrm{OC}$ aerosol mass concentrations above the boundary layer. The ITCT-2K4 observations provide the second such data set. They are far more extensive than the ACE-Asia observations, benefit from much better ancillary chemical information, and also include continental boundary layer information. WSOC can be expected to account for the bulk of $\mathrm{OC}$ aerosol in the free troposphere, considering the high degree of internal mixing of organic and inorganic aerosol components reported by Murphy et al. [2006].

[33] The mean observed WSOC aerosol concentration in the free troposphere during ITCT $2 \mathrm{~K} 4$ was $1.7 \mu \mathrm{g} \mathrm{C} \mathrm{m}^{-3}$, a factor of 2 lower than in ACE-Asia. Extremely high concentrations (up to $26 \mu \mathrm{g} \mathrm{C} \mathrm{m}^{-3}$ ) were observed in plumes from large boreal fires in Alaska and northwestern Canada that raged for much of the summer of 2004 (Turquety et al., submitted manuscript, 2006). We filtered these biomassburning plumes ( $9 \%$ of the free tropospheric data set) using correlation with observed acetonitrile [de Gouw et al., 2006] The filtered data set yields a mean free tropospheric WSOC concentration of $0.9 \pm 0.9 \mu \mathrm{g} \mathrm{C} \mathrm{m}{ }^{-3}$ with a lognormal 
distribution. WSOC is not correlated with acetonitrile in this filtered data set, suggesting that biomass burning was not a dominant source outside of plumes.

[34] Our GEOS-Chem simulation of the ITCT-2K4 data includes a daily resolved inventory of emissions from the summer 2004 boreal fires, evaluated with MOPITT CO observations (Turquety et al., submitted manuscript, 2006). The $\mathrm{OC} / \mathrm{CO}$ emission ratio in that fire inventory is $0.23 \mathrm{~mol}$ $\mathrm{C} \mathrm{mol}^{-1}$ [Andreae and Merlet, 2001]. The observed WSOC/CO enhancement ratio in the ITCT-2K4 fire plumes is $40 \%$ lower, but this is reproduced in the corresponding model plumes and appears to reflect dilution of fire plumes and scavenging of OC aerosol. This scavenging is highly sensitive to the injection altitude of the fire emissions. Our standard GEOS-Chem simulation injects $60 \%$ of fire emissions in the free troposphere at $3-5 \mathrm{~km}$ altitude, based on evidence of extensive pyroconvection as well as the information offered by the MOPITT data (Turquety et al., submitted manuscript, 2006) and the fire plume trajectories [de Gouw et al., 2006].

[35] Comparison of simulated vs. observed mean vertical profiles of WSOC aerosol concentrations, for the filtered data set excluding biomass-burning plumes, indicates a $30 \%$ model underestimate in the continental boundary layer and a $25 \%$ underestimate in the free troposphere. Observed WSOC aerosol concentrations in the boundary layer are consistent with surface air observations of OC aerosol concentrations at the IMPROVE network of long-term monitoring sites. They are on average a factor of 2 higher than in the free troposphere, and include an important anthropogenic source apparent in the correlation with $\mathrm{CO}$ [Sullivan et al., 2006]. The model attributes WSOC in the boundary layer on average as $49 \%$ primary anthropogenic, $27 \%$ biomass burning, and $24 \%$ biogenic SOA. The model reproduces the observed correlation of WSOC aerosol with $\mathrm{CO}$ but the corresponding slope is a factor of 2 too low. This suggests a secondary SOA source, which may be either biogenic or anthropogenic in origin, missing from the model and of magnitude comparable to primary anthropogenic emission.

[36] We find that the boundary layer OC aerosol budget is disconnected from that in the free troposphere. Simulated and observed vertical profiles of $\mathrm{SO}_{\mathrm{x}}$ show a factor of 10 decrease from the boundary layer to the free troposphere, indicating efficient scavenging (well reproduced by the model). Combined with evidence that boundary layer OC aerosol is mainly water-soluble, we find in the model that the anthropogenic source is minor above $3 \mathrm{~km}$ and that biomass burning (42\%) and biogenic SOA (36\%) are then the principal sources of WSOC aerosol. Biogenic SOA in the model contributes $0.2-0.5 \mu \mathrm{g} \mathrm{C} \mathrm{m}^{-3}$ in the free troposphere, of which $15-30 \%$ is from oxidation of isoprene through gas-aerosol partitioning of semivolatile oxidation products [Henze and Seinfeld, 2006].

[37] The ability of the model to match within $25 \%$ the mean free tropospheric OC aerosol concentrations observed in the ITCT-2K4 data is in sharp contrast with the factor of 10-100 underestimate of the ACE-Asia observations [Heald et al., 2005]. The ITCT-2K4 data averaged $0.9 \pm$ $0.9 \mu \mathrm{g} \mathrm{C} \mathrm{m}^{-3}$ for the filtered free tropospheric data set excluding biomass-burning plumes, which is 4 times less than the average for ACE-Asia $\left(3.3 \pm 2.8 \mu \mathrm{g} \mathrm{C} \mathrm{m}^{-3}\right)$.
Simulated OC aerosol concentrations for ITCT-2K4 were over a factor of 2 higher than in ACE-Asia due the larger contributions from biomass burning and biogenic SOA. The source of the high OC aerosol observed in ACE-Asia thus remains unclear.

[38] Although the GEOS-Chem model is relatively successful in reproducing the mean free tropospheric WSOC aerosol concentrations observed in ITCT-2K4, it does not reproduce the variance in the individual observations $(R=$ 0.21 ), suggesting that the underlying sources are not properly represented. We conducted a correlation analysis for the ensemble of chemical variables measured aboard the aircraft and found that the measured free tropospheric WSOC aerosol correlates most strongly $(R>0.35)$ with methanol and sulfate. Multivariate correlations using methanol in combination with sulfate, nitric acid or toluene can explain up to $28 \%$ of the variability $(R=0.54)$. The correlation with methanol and sulfate supports an in-cloud formation mechanism from biogenic VOC precursors, as previously suggested by Lim et al. [2005] and Carlton et al. [2006]. The added correlation with nitric acid suggests that SOA could be supplied to the free troposphere by venting of fair weather cumuli where SOA formation would take place. The correlation with toluene suggests a persisting though likely minor role for anthropogenic SOA in the free troposphere.

[39] Our previous analysis of the elevated free tropospheric OC aerosol concentrations in the ACE-Asia data [Heald et al., 2005] pointed to potentially large implications for radiative forcing and intercontinental transport of aerosol pollution. The high WSOC aerosol concentrations observed in ITCT-2K4 (though a factor of 4 lower than ACE-Asia) confirm the importance of free tropospheric OC aerosol for radiative forcing $\left(-0.26 \mathrm{Wm}^{-2}\right.$, for the mean 2-6 km aerosol column observed in ITCT-2K4, calculated with the same assumptions as Heald et al. [2005]). The decoupling of the boundary layer and the free troposphere seen in ITCT-2K4 for the WSOC aerosol, together with the apparent dominance of natural sources in the free troposphere, implies that intercontinental transport of OC aerosol pollution affecting U.S. aerosol air quality would be minimal in summer. The issue deserves further examination in spring, when the ACE-Asia measurements were made and when transpacific transport of Asian pollution is strongest.

[40] Acknowledgments. This work was supported by the U.S. Environmental Protection Agency STAR program, the Electrical Power Research Institute (EPRI), and a NOAA Postdoctoral Fellowship in Climate and Global Change for CLH, administered by the University Corporation for Atmospheric Research. We thank Rokjin Park and Daven Henze for useful discussions.

\section{References}

Andreae, M. O., and P. Merlet (2001), Emission of trace gases and aerosols from biomass burning, Global Biogeochem. Cycles, 15, 955-966.

Andreae, M. O., D. Rosenfeld, P. Artaxo, A. A. Costa, G. P. Frank, K. M. Longo, and M. A. F. Silva-Dias (2004), Smoking rainclouds over the Amazon, Science, 303(5662), 1337-1342.

Bond, T. C., D. G. Streets, K. F. Yarber, S. M. Nelson, J.-H. Woo, and Z. Klimont (2004), A technology-based global inventory of black and organic carbon emissions from combustion, J. Geophys. Res., 109, D14203, doi:10.1029/2003JD003697.

Carlton, A. G., B. J. Turpin, H.-J. Lim, and K. E. Altieri (2006), Link between isoprene and secondary organic aerosol (SOA): Pyruvic acid 
oxidation yields low volatility organic acids in clouds, Geophys. Res. Lett., 33, L06822, doi:10.1029/2005GL025374.

Chung, S. H., and J. H. Seinfeld (2002), Global distribution and climate forcing of carbonaceous aerosols, J. Geophys. Res., 107(D19), 4407, doi:10.1029/2001JD001397.

Cooke, W. F., C. Liousse, H. Cachier, and J. Feichter (1999), Construction of a $1^{\circ} \times 1^{\circ}$ fossil fuel emission data set for carbonaceous aerosol and implementation and radiative impact in the ECHAM4 model, J. Geophys. Res., 104, 22,137-22,162.

Damoah, R., N. Spichtinger, R. Servranckx, M. Fromm, E. W. Eloranta, I. A. Razenkov, P. James, M. Shulski, C. Forster, and A. Stohl (2006), A case study of pyro-convection using transport model and remote sensing data, Atmos. Chem. Phys., 6, 173-185.

Decesari, S., M. C. Facchini, E. Matta, F. Lettini, M. Mircea, S. Fuzzi, E. Tagliavini, and J.-P. Putaud (2001), Chemical features and sesonal varition of fine aerosol water-soluble organic compounds in the $\mathrm{Po}$ Valley, Italy, Atmos. Environ., 35, 3691-3699.

de Gouw, J. A., et al. (2005), Budget of organic carbon in a polluted atmosphere: Results from the New England Air Quality Study in 2002 J. Geophys. Res., 110, D16305, doi:10.1029/2004JD005623.

de Gouw, J. A., et al. (2006), Volatile organic compounds composition of merged and aged forest fire plumes from Alaska and western Canada, J. Geophys. Res., 111, D10303, doi:10.1029/2005JD006175.

Fromm, M., and R. Servranckx (2003), Transport of forest fire smoke above the tropopause by supercell convection, Geophys. Res. Lett., 30(10), 1542, doi:10.1029/2002GL016820.

Fromm, M., J. Alfred, K. Hoppel, J. Hornstein, R. Bevilacqua, E. Shettle, R. Servranckx, Z. Li, and B. Stocks (2000), Observations of boreal forest fire smoke in the stratosphere by POAM III, SAGE II, and lidar in 1998, Geophys. Res. Lett., 27, 1407-1410.

Fromm, M., R. Bevilacqua, R. Servranckx, J. Rosen, J. P. Thayer, J. Herman, and D. Larko (2005), Pyro-cumulonimbus injection of smoke to the stratosphere: Observations and impact of the super blowup in northwestern Canada on 3-4 August 1998, J. Geophys. Res., 110, D08205, doi:10.1029/2004JD005350.

Guenther, A., et al. (1995), A global model of natural volatile organic compound emissions, J. Geophys. Res., 100, 8873-8892.

Heald, C. L., D. J. Jacob, R. J. Park, L. M. Russell, B. J. Huebert, J. H. Seinfeld, H. Liao, and R. J. Weber (2005), A large organic aerosol source in the free troposphere missing from current models, Geophys. Res. Lett., 32, L18809, doi:10.1029/2005GL023831.

Heald, C. L., D. J. Jacob, R. J. Park, B. Alexander, T. D. Fairlie, R. M Yantosca, and D. A. Chu (2006), Transpacific transport of Asian anthropogenic aerosols and its impact on surface air quality in the United States, J. Geophys. Res., 111, D14310, doi:10.1029/2005JD006847.

Henze, D. K., and J. H. Seinfeld (2006), Global secondary organic aeroso from isoprene oxidation, Geophys. Res. Lett., 33, L09812, doi:10.1029/ 2006 GL025976.

Hirsch, R. M., and E. J. Gilroy (1984), Methods of fitting a straight line to data: Examples in water resources, Water Resour. Bull., 20, $705-711$.

Holloway, J. S., R. O. Jakoubek, D. D. Parrish, C. Gerbig, A. Volz-Thomas, S. Schmitgen, A. Fried, B. Wert, B. Henry, and J. R. Drummond (2000), Airborne intercomparison of vacuum ultraviolet fluorescence and tunable diode laser absorption measurements of tropospheric carbon monoxide, J. Geophys. Res., 105, 24,251-24,261.

Holzinger, R., C. Warneke, A. Hansel, A. Jordon, W. Lindinger, D. H. Scharffe, G. Schade, and P. J. Crutzen (1999), Biomass burning as a source of formaldehyde, acetaldehyde, methanol, acetone, acetonitrile, and hydrogen cyanide, Geophys. Res. Lett., 26, 1161-1164.

IPCC (2001), Climate Change 2001: The Scientific Basis, edited by J. T. Houghton et al., Cambridge Univ. Press, New York.

Jacob, D. J., B. D. Field, Q. Li, D. R. Blake, J. de Gouw, C. Warneke, A. Hansel, A. Wisthaler, and H. B. Singh (2005), Global budget of methanol: Constraints from atmospheric observations, J. Geophys. Res., 110, D08303, doi:10.1029/2004JD005172.

Jaffrezo, J.-L., G. Aymoz, C. Delaval, and J. Cozic (2005), Seasonal variations of the water soluble organic carbon mass fraction of aerosol in two valleys of the French Alps, Atmos. Chem. Phys., 5, 2809-2821.

Johnson, D., S. R. Utembe, M. E. Jenkin, R. G. Derwent, G. D. Hayman, M. R. Alfarra, H. Coe, and G. McFiggans (2006), Simulating regiona scale secondary organic aerosol formation during the TORCH 2003 campaign in the southern UK, Atmos. Chem. Phys., 6, 403-418.

Kroll, J. H., N. L. Ng, S. M. Murphy, R. C. Flagan, and J. H. Seinfeld (2005), Secondary organic aerosol formation from isoprene photooxidation under high-NO $\mathrm{NO}_{\mathrm{x}}$ conditions, Geophys. Res. Lett., 32, L18808, doi:10.1029/2005GL023637.

Lewis, A. C., et al. (2006), Chemical composition observed over the midAtlantic and the longevity of pollution signatures far from source regions, J. Geophys. Res., doi:10.1029/2006JD007584, in press.
Li, Q. B., et al. (2005), North American pollution outflow and the trapping of convectively lifted pollution by upper-level anticyclone, J. Geophys. Res., 110, D10301, doi:10.1029/2004JD005039.

Lim, H. J., A. G. Carlton, and B. J. Turpin (2005), Isoprene forms secondary organic aerosol through cloud processing: Model simulations, Environ Sci. Technol., 39(12), 4441-4446.

Limbeck, A., and H. Puxbaum (2000), Dependence of in-cloud scavenging of polar organic compounds on the water solubility, J. Geophys. Res., 105(D15), 19,857-19,867

Liu, H., D. J. Jacob, I. Bey, and R. M. Yantosca (2001), Constraints from ${ }^{210} \mathrm{~Pb}$ and ${ }^{7} \mathrm{Be}$ on wet deposition and transport in a global threedimensional chemical tracer model driven by assimilated meteorological fields, J. Geophys. Res., 106, 12,109-12,128.

Malm, W. C., J. F. Sisler, D. Huffman, R. A. Eldred, and T. A. Cahill (1994), Spatial and seasonal trends in particulate concentration and optical extinction in the United States, J. Geophys. Res., 99, 1347-1370.

McKeen, S. A., S. C. Liu, E.-Y. Hsie, X. Lin, J. D. Bradshaw, S. Smyth, G. L. Gregory, and D. R. Blake (1996), Hydrocarbon ratios during PEM-WEST A: A model perspective, J. Geophys. Res., 101, 20872109

Millet, D. B., et al. (2006), Formaldehyde distribution over North America: Implications for satellite retrievals of formaldehyde columns and isoprene emission, J. Geophys. Res., 111, D24S02, doi:10.1029/2005JD006853.

Morris, G. A., et al. (2006), Alaskan and Canadian forest fires exacerbate ozone pollution over Houston, Texas, on 19 and 20 July 2004, J. Geophys. Res., 111, D24S03, doi:10.1029/2006JD007090.

Murphy, D. M., D. J. Cziczo, K. D. Froyd, P. K. Hudson, B. M. Matthew, A. M. Middlebrook, R. E. Peltier, A. Sullivan, D. S. Thomson, and R. J. Weber (2006), Single-particle mass spectrometry of tropospheric aerosol particles, J. Geophys. Res., 111, D23S32, doi:10.1029/2006JD007340.

Neuman, J. A., et al. (2002), Fast-response airborne in situ measurements of HNO3 during the Texas air Quality Study, J. Geophys. Res., 107(D20), 4436, doi:10.1029/2001JD001437.

Nowak, J., J. A. Neuman, K. Kozai, G. Huey, D. J. Tanner, J. S. Holloway, T. B. Ryerson, G. J. Frost, S. A. McKeen, and F. C. Fehsenfeld (2007), A chemical ionization mass spectrometry technique for airborne measurements of ammonia, J. Geophys. Res., 112, doi:10.1029/2006JD007589, in press.

Odum, J. R., T. P. W. Jungkamp, R. J. Griffin, H. J. L. Forstner, R. C. Flagan, and J. H. Seinfeld (1997), Aromatics, reformulated gasoline, and atmospheric organic aerosol formation, Environ. Sci. Technol., 31(7), $1890-1897$

Park, R. J., D. J. Jacob, M. Chin, and R. V. Martin (2003), Sources of carbonaceous aerosols over the United States and implications for natural visibility, J. Geophys. Res., 108(D12), 4355, doi:10.1029/ 2002JD003190.

Park, R. J., D. J. Jacob, B. D. Field, R. M. Yantosca, and M. Chin (2004), Natural and transboundary pollution influences on sulfate-nitrateammonium aerosols in the United States: implications for policy, J. Geophys. Res., 109, D15204, doi:10.1029/2003JD004473.

Park, R. J., et al. (2005), Export efficiency of black carbon aerosol in continental outflow: Global implications, J. Geophys. Res., 110 D11205, doi:10.1029/2004JD005432.

Park, R. J., D. J. Jacob, N. Kumar, and R. M. Yantosca (2006), Regional visibility statistics in the United States: Natural and transboundary pollution influences, and implications for the regional haze rule, Atmos. Environ., in press.

Parrish, D. D., et al. (2004), Fraction and composition of $\mathrm{NO}_{\mathrm{y}}$ transported in air masses lofted from the North American continental boundary layer, J. Geophys. Res., 109, D09302, doi:10.1029/2003JD004226.

Reid, J. S., R. Koppmann, T. F. Eck, and D. P. Eleuterio (2005), A review of biomass burning emissions, part II: Intensive physical properties of biomass burning properties, Atmos. Chem. Phys., 5, 799-825.

Ryerson, T. B., et al. (1998), Emissions lifetimes and ozone formation in power plant plumes, J. Geophys. Res., 103, 22,569-22,583.

Ryerson, T. B., L. G. Huey, K. Knapp, J. A. Neuman, D. D. Parrish, D. T. Sueper, and F. C. Fehsenfeld (1999), Design and initial characterization of an inlet for gas-phase NOy measurements from aircraft, J. Geophys. Res., 104, 5483-5492.

Ryerson, T. B., E. J. Williams, and F. C. Fehsenfeld (2000), An efficient photolysis system for fast-response $\mathrm{NO}_{2}$ measurements, J. Geophys. Res. $105,26,447-26,461$

Saxena, P., and L. M. Hildemann (1996), Water-soluble organics in atmospheric particles: A critical review of the literature and application of thermodynamics to identify candidate compounds, J. Atmos. Chem., 24(1), 57-109.

Schauffler, S. M., E. L. Atlas, D. R. Blake, F. Flocke, R. A. Lueb, J. M. Lee-Taylor, V. Stroud, and W. Travnicek (1999), Distributions of brominated organic compounds in the troposphere and lower stratosphere, J. Geophys. Res., 104, 21,513-21,536. 
Singh, H. B., et al. (2003), In situ measurements of $\mathrm{HCN}$ and $\mathrm{CH} 3 \mathrm{CN}$ over the Pacific Ocean: Sources, sinks, and budgets, J. Geophys. Res., 108(D20), 8795, doi:10.1029/2002JD003006.

Slusher, D. L., L. G. Huey, D. J. Tanner, F. Flocke, and J. M. Roberts (2004), A thermal dissociation-chemical ionization mass spectrometry (TD-CIMS) technique for the simultaneous measurement of peroxyacyl nitrates and dinitrogen pentoxide, J. Geophys. Res., 109, D19315, doi:10.1029/2004JD004670

Sullivan, A. P., R. E. Peltier, C. A. Brock, J. A. de Gouw, J. S. Holloway, C. Warneke, A. G. Wollny, and R. J. Weber (2006), Airborne measurements of carbonaceous aerosol soluble in water over northeastern United States: Method development and an investigation into water-soluble organic carbon sources, J. Geophys. Res., 111, D23S46, doi:10.1029/ 2006JD007072.

Tsigaridis, K., and M. Kanakidou (2003), Global modeling of secondary organic aerosol in the troposphere: A sensitivity analysis, Atmos. Chem. Phys. Disc., 3, 2879-2929.

van Donkelaar, A., R. V. Martin, and R. J. Park (2006a), Estimating groundlevel $\mathrm{PM}_{2.5}$ with aerosol optical depth determined from satellite remote sensing, J. Geophys. Res., 111, D21201, doi:10.1029/2005JD006996.

van Donkelaar, A., R. V. Martin, R. J. Park, C. L. Heald, T.-M. Fu, H. Liao, and A. Guenther (2006b), Model evidence for a significant source of secondary organic aerosol from isoprene, Atmos. Environ., in press.

Volkamer, R., et al. (2006), Secondary organic aerosol formation from anthropogenic air pollution: Rapid and higher than expected, Geophys Res. Lett., 33, L17811, doi:10.1029/2006GL026899.

Wang, Y., D. J. Jacob, and J. A. Logan (1998), Global simulation of tropospheric $\mathrm{O}_{3}-\mathrm{NO}_{\mathrm{x}}$-hydrocarbon chemistry: 1. Model formulation, J. Geophys. Res., 103, 10,713-10,725.

Weber, R. J., D. Orsini, Y. Daun, Y.-N. Lee, P. Klotz, and F. Brechtel (2001), A particle-in-liquid collector for rapid measurement of aerosol chemical composition, Aerosol Sci. Technol., 35, 718-727.
Zhang, Q., D. R. Worsnop, M. R. Canagaratna, and J. L. Jimenez (2005), Hydrocarbon-like and oxygenated organic aerosols in Pittsburgh: Insights into sources and processes of organic aerosols, Atmos. Chem. Phys., 5, $3289-3311$

E. L. Atlas, Rosentiel School of Marine and Atmospheric Science, 4600 Rickenbacker Causeway, University of Miami, Miami, FL 33149, USA. (eatlas@rsmas.miami.edu)

J. A. de Gouw, J. S. Holloway, J. A. Neuman, and C. Warneke, Chemical Sciences Division, NOAA Earth System Research Laboratory, Boulder, CO 80303, USA. (joost.degouw@noaa.gov; john.s.holloway@noaa.gov; andy.neuman@noaa.gov; carsten.warneke@noaa.gov)

F. M. Flocke, National Center for Atmospheric Research, 1850 Table Mesa Drive, Boulder, CO 80303, USA. (ffl@ucar.edu)

C. L. Heald, Center for Atmospheric Sciences, 301 McCone MC4767, University of California, Berkeley, CA 94705-4767, USA. (heald@atmos. berkeley.edu)

R. C. Hudman and D. J. Jacob, Division of Engineering and Applied Science, Harvard University, 29 Oxford Street, Cambridge, MA 02138 , USA. (rch@io.harvard.edu; djj@io.harvard.edu)

R. E. Peltier, A. P. Sullivan, and R. J. Weber, School of Earth and Atmospheric Sciences, Georgia Institute of Technology, 311 Ferst Drive, Atlanta, GA 30332-0340, USA. (rpeltier@eas.gatech.edu; asullivan@ eas.gatech.edu; rweber@eas.gatech.edu)

J. H. Seinfeld, Department of Chemical Engineering, California Institute of Technology, 1200 E. California Blvd, Pasadena, CA 91125, USA. (seinfeld@caltech.edu)

S. Turquety, Service d'Aeronomie, IPSL, 4 Place Jussieu, 75252 Paris Cedex 05, France. (turquety@aero.jussieu.fr) 